Artur Staszczyk

\title{
THE EUROPEAN PARLIAMENT IN VIEW OF THE DEVELOPMENT OF THE EU SECURITY AND DEFENCE POLICY AFTER THE LISBON TREATY
}

Keywords: Parliament, security, defence, European Union.

\begin{abstract}
This article analyses the position of the European Parliament on the priorities for the development of the EU Common Security and Defence Policy. The issues covered by this policy after the entry into force of the Lisbon Treaty remained the domain of intergovernmental cooperation mechanisms. Despite the changes made to the Lisbon Treaty to unify the Union's external relations by removing its pillars and expanding CSDP tasks, the role of the EP in its creation has not increased in line with its expectations. In accordance with the provisions of the TEU, decisions on the operation of the CSDP shall be adopted by the Council, acting unanimously on a proposal from the High Representative of the Union for Foreign Affairs and Security Policy or from a Member State. As a result of such Treaty arrangements, the EP is unable to play such a role in the area of CSDP that would correspond to the importance of this body in the EU's institutional system. Therefore, the main instrument for the implementation of the EP policy in the area of CSDP remain resolutions in which this body calls for the inclusion of transnational cooperation mechanisms in it. By expressing its position in resolutions, the EP advocates for the development of a strong, unified CSDP based on defined European security interests, as well as the development of a pan-European approach to the issues covered by this policy.
\end{abstract}

1 Artur Staszczyk, ORCID: 0000-0001-9769-8991, PhD in Politic Science, university lecturer at the Department of International Relations and European Studies of the Institute of Political Science and European Studies at Szczecin University. His research interest includes such issues as: the EU's Foreign and Security Policy, European Neighbourhood Policy, the role of European Parliament in the formation of the EU's external relations. 


\section{INTRODUCTION}

Establishing the European Communities (EC) in the 1950s gave the process of European integration basically the character of economic cooperation. Security integration issues as a result of the failure to implement the project to establish a supranational European Defence Community (EDC) have not become a priority for the leaders of the Western European countries. The establishment of a new intergovernmental security structure, the Western European Union (WEU), at the initiative of the United Kingdom, did not change this. Established on 23 October 1954 in Paris under the agreements amending the Brussels Treaty, this organisation could not fill the security integration gap created by the collapse of the EDC project. The reason for this state of affairs was the WEU's military dependence and the submission to NATO's strategy and policy, which became the most important security structure for the Western European countries. This reflected the geopolitical situation at the time, which made the USA, through the existence of NATO, the most important element of the Western European military system and a guarantor of security for the countries of the European Community. The existence of the American nuclear umbrella guaranteeing the security of Western Europe, as well as the conflict of interests of individual EC countries, has led to a lack of interest on the part of Europeans in the creation of supranational security structures. Only in the mid-1980s the WEU has started to become a forum for the exchange of views on the redefinition of European interests in the field of security and defence. The search for a European security identity has been accelerated by the fall of the Iron Curtain and the collapse of the bipolar system of international relations. The emergence of a new geopolitical situation in Europe, accompanied by a number of conflicts, gave impetus to the establishment of the Common Foreign and Security Policy (CFSP) as the second pillar of the European Union (EU) - an organisation established on 7 February 1992 under the Maastricht Treaty, which entered into force on 1 November 1993 (Zięba, 2005a, pp. 9-19).

In the course of work on the draft of Treaty on European Union (TEU), two concepts of regulating the relationship between the EU and the WEU emerged. One of them assumed the establishment of a strong CFSP within the EU and, in the future, a common defence policy aimed at establishing a common de- 
fence. Under this concept, the WEU was to become an integral part of the EU. The second concept assumed that the WEU would retain its autonomous character in relation to the EU, NATO would remain the most important security structure of Western Europe, and the CFSP would operate on the basis of intergovernmental cooperation mechanisms. Ultimately, the solutions adopted in the TEU were based on the second concept promoted by the United Kingdom. The Maastricht Treaty distinguishes between security matters that have been the subject of CFSP action and defence matters that are reserved to the WEU as an integral part of the EU's development. The increased importance of the WEU in the process of European integration took place with the entry into force of the Amsterdam Treaty. Despite the fact that it was not decided to incorporate the WEU into the EU, the EU has become an operational tool used for military operations in the field of Petersberg missions (humanitarian, rescue, peacekeeping, enforced crisis resolution). Final decisions extending the scope of CFSP action to military crisis response operations were taken at the European Council in Cologne (June 1999), where guidelines establishing a European Security and Defence Policy (ESDP) were adopted, and in Helsinki (December 1999), where the decision to create an EU force was taken. These decisions were sanctioned by the Treaty of Nice, which equipped the EU with the capacity to conduct Petersberg operations alone. This was possible as a result of the earlier decision of the Ministerial Council of the WEU to transfer its operational functions and structures to the EU (Zięba, 2005b, pp. 14-20). The establishment of the ESDP was made possible by the activity of France and Germany, who understood that without a strong and unified ESDP, the EU would not be able to shape international policy on the basis of its values. However, the view that the EU should be both a civilian and a military force capable of carrying out crisis response operations was accompanied by a dispute between supporters of the European option (France, Germany) and the Atlantic option (United Kingdom) over the scope of the transfer of sovereign state powers to ESDP level. While for Germany the priority was to create transnational mechanisms at ESDP level, the United Kingdom was very sceptical about this concept (Hürsoy, 2002, pp. 84-85). Finally, the view that ESDP would be primarily intergovernmental in nature prevailed, as confirmed by the provisions of the Lisbon Treaty, which renamed the policy the Common Security and Defence Policy (CSDP). The CSDP tasks have been extended. Joint disarmament activi- 
ties, military advisory and support missions, post-crisis stabilization operations have been added to the catalogue of previously implemented Petersberg tasks. All CSDP activities should also contribute to the fight against terrorism and support third countries in their fight against terrorism. In accordance with the provisions of Section 2 of Chapter 2 of Title 5 of the TEU, the CSDP is an integral part of the CFSP, ensuring the EU's operational capability to act outside the Union. Decisions on the operation of the CSDP, including those relating to the undertaking of missions, in accordance with the provisions of the TEU, shall be adopted by the Council, acting unanimously on a proposal from the High Representative of the Union for Foreign Affairs and Security Policy or a Member State (Treaty..., 2016, pp. 38-39).

It should be underlined that from the very beginning, the ESDP/CSDP has been a source of controversy among its creators as to its substance and the objective it should achieve. While in France the CSDP was seen as a tool for the political integration of Europe, in the United Kingdom it was defined as an instrument designed to improve European military capabilities and thus revitalise NATO's functioning. However, as a result of the EU's crisis response experience in, inter alia, the Balkans, the CSDP concept has been modified. The CSDP has prioritised not military crisis management operations, but long-term civilian operations and activities in the area of counter-terrorism and counterproliferation of weapons of mass destruction. Quite apart from the views that the CSDP is a logical consequence of the development of the European integration process or that it merely confirms the chaotic path of EU foreign policy development, one has to agree with the view that the emergence and functioning of the CSDP means an increase in the EU's capacity to intervene in international security matters. The CSDP is a practical tool for intervention through the development of CSDP bodies and the coordination and mobilisation of EU military and civilian capabilities (Bickerton, Irondelle, Menon, 2011, pp. 3-4).

The domination of intergovernmental cooperation mechanisms under the Common Security and Defence Policy (CSDP), despite the name suggesting its communitarisation, results in the fact that the main entities creating it are EU Member States. For this reason, supranational institutions such as the European Parliament (EP) do not have any real power in relation to the CSDP, but only act as advisory, consultative and opinion bodies. However, this does not mean that the EP has no significant influence on the shape of the CSDP. 
Therefore, the main aim of the article is to analyse the position of the EP as an EU body with supranational status in relation to the evolution of CSDP functioning as well as the most important issues falling within the scope of this policy. It should be stressed that the EP, despite the lack of decision-making powers in the area of CSDP, especially after the entry into force of the Lisbon Treaty, which transformed the EU into a single international legal structure, began to aspire to play an increasing role in the field of the EU's security and defence policy. This role does not derive from the prerogatives of the EP under the Treaty, but results primarily from the fact that the EP is an institution of political influence in relation to other EU bodies, thanks to its democratic legitimacy and control function (parliamentary debates, resolutions, recommendations, reports). The main instrument of influence are non-legislative resolutions passed by this body. These documents, although are not a part of the decisionmaking process and devoid of legally binding force, allow the body to express its position on the CSDP and to influence it indirectly. Due to the fact that the functioning of the EU is characterised by a high level of institutionalisation, and for the author the key research challenge in this publication is the analysis of texts of resolutions adopted by a supranational institution such as the EP, for the purposes of this article the research method, which is institutional and legal analysis, has also been applied (Chodubski, 2012, pp. 25). Its application allows us to get to know the EP's opinion on the development of civilian and military capabilities of the EU under the CSDP and to answer the question what is the EP's preferred concept of the functioning of this policy.

\section{THE EUROPEAN PARLIAMENT IN VIEW OF THE IMPLEMENTATION OF THE COMMON SECURITY AND DEFENCE POLICY}

The European Security Strategy (ESS) formulated by the European Council (EC) in December 2003 had a significant impact on the EU civilian and military capability building process. The emergence of this document was a consequence of the unifying Europe's perception of new asymmetric dimensions of security such as: migration, terrorism, energy security, cyber security. The Strategy, which is a set of challenges and threats facing the EU in the field of se- 
curity, also lists the EU's strategic objectives in this area as well as the proposals for CFSP and ESDP (Koziej, 2011, pp. 19-40). The changes taking place in the EU environment, generating new challenges and threats to its security, made it necessary for the Union to adopt a new strategic document. In June 2016 The European Council approved a document called the EU Global Strategy on Foreign and Security Policy, which sets out the Union's common interests, principles and priorities for action in this area. One of the priorities of the Strategy was the security of the Union itself. The directions of action under this priority include security and defence, combating terrorism, cyber security, energy security, information security - strategic communication (Globalna strategia..., 2016, pp. 16-20).

The CSDP has been identified as the most important tool for the implementation of the Strategy and has been identified as an essential instrument for crisis prevention and resolution. In the EP's view, in order to be a more effective and credible global actor, the Union needs to take greater responsibility in the field of security in its immediate and wider neighbourhood. It must therefore have the necessary civilian and military resources and aspire to be a rule-setter, contributing to the creation of an effective multilateral global order based on democracy, good governance, the rule of law and human rights (Rezolucja..., 2016a). The EP underlines that the EU faces unprecedented conventional and hybrid challenges, as social, economic, technological and geopolitical trends point to the increasing vulnerability of the world population to shocks and tensions, such as inter-state conflicts, natural disasters, extreme weather events, water crises, state collapses and cyber-attacks, which require concerted and coordinated action. In the EP's view, no Member State can meet all the security challenges on its own and, in order to act effectively on the international stage, EU countries need to act together to tackle the causes of fragility, such as poverty, growing inequality, poor governance, state failure and climate change. To this end, a common defence should be established and the Union should be given strategic autonomy to enable it to promote peace and security in Europe and throughout the world. The EP stresses that the EU must use soft and hard power policy instruments, which are a compilation of civil and military measures, in order to meet emerging challenges. The CSDP should be based on the principle that security in Europe cannot be guaranteed by military means alone. In order to achieve this objective, it is necessary for those responsible 
for civil, development and humanitarian issues to cooperate with each other (Rezolucja..., 2017).

According to the EP, the key issue for the functioning of the CSDP is the establishment of security and defence relations between the EU and NATO, as these organisations have the same strategic interests and face the same challenges in the east and south. The EP draws attention to the importance of the mutual defence clause (Article 42 (7)) for EU Member States, both for those that are members of NATO and for non-alliance countries, and notes that the EU should be able to protect non-NATO EU Member States to the same extent using its own resources. It draws attention to the objective of an appropriate level of strategic autonomy for the EU, as outlined in the European Union's global strategy on foreign and security policy, and stresses that the two organisations must demonstrate complementarity of resources. It considers that the so-called strategic autonomy of the EU should enhance Europe's ability to promote security within and beyond its borders and strengthen its partnership with NATO and transatlantic relations. It emphasises that relations between the two organisations must continue to be based on cooperation rather than competition. This is due to the fact that NATO has excellent deterrence and defence capabilities and is ready to activate a collective defence mechanism (Article V of the Washington Treaty) in the event of aggression against one of its members, while the CSDP currently focuses on peacekeeping, conflict prevention and strengthening international security (Article 42 TEU). Furthermore, the EP fully supports the further strengthening of cooperation on security and defence with other institutional partners, including the UN, the African Union and the OSCE, as well as with strategic bilateral partners, notably the US, in areas such as hybrid threats, maritime security, rapid response, the fight against terrorism and cyber security (Rezolucja..., 2016b). The EP is of the opinion that strengthening the EU's civilian and military capabilities will also benefit NATO, as it will create synergies between the two organisations. NATO for the EP remains the foundation of collective defence in Europe and cooperation between the two organisations should strengthen their strategic partnership. According to the EP, the EU and NATO should, in particular, cooperate in the field of crisis management while respecting mutual autonomy in the decisionmaking process. The EP also draws attention to the need to avoid unnecessary overlaps between the activities and resources of the two organisations and calls 
on NATO to strictly limit civil capacity-building in order to avoid duplication of tasks. Furthermore, the EP notes that the existence of a common EU defence policy makes it necessary to integrate European armed forces and equip them with common weapons systems guaranteeing uniformity and interoperability. It therefore criticises the practice of the widespread duplication of defence programmes within the Union, as well as the policy of the Member States with regard to the inadequate provision of their military resources to the Union, which is delaying the process of forming a European armed force. In its resolutions, the EP calls on the Member States to support the European Defence Agency as an EU expert agency entrusted with the task of identifying and developing defence capabilities in the field of crisis management and promoting and strengthening European armaments cooperation. It calls for a debate with its participation on the implementation of the provisions of the Lisbon Treaty concerning the mutual assistance clause in the event of aggression on the territory of an EU Member State. It takes the view that this clause is legally binding in the event of external aggression against any EU Member State and does not prejudice NATO's role as a guarantor of European security (Rezolucja..., 2011). The EP therefore criticises the lack of interest of CSDP decision-making bodies and Member States in the implementation of this clause. The lack of progress in CSDP implementation due to the trend over the years towards lower defence spending by Member States and the marginalisation of the policy's instruments and capabilities is, in the EP's view, in danger of the EU's strategic collapse because it drastically reduces its ability to fulfil its peacekeeping, conflict prevention and the strengthening of international security tasks. In order to prevent strategic degradation, the EU should have an effective permanent armed force (EU Battlegroups) with a high level of preparedness to deal with crisis situations, consisting of air, naval, cyber defence and special forces. In addition, in order to ensure optimal operation of the CSDP, it is necessary, inter alia, to strengthen the industrial and technological base of the European defence sector, to extend the European preference to arms purchases, to establish political and strategic guidelines imposing obligations on EU countries to develop their military capabilities, to lay the foundations for joint planning from strategic planning through public procurement to technological development, to accelerate the implementation of projects such as satellite communications, cyber defence and the Single European Sky. It should be stressed that the EP recog- 
nises the link between the development of the European Defence Technological and Industrial Base, which supports the CSDP, and economic growth, competitiveness and the creation of new jobs (Rezolucja..., 2012; Rezolucja..., 2013).

The EP notes that the current state of the CSDP does not allow the EU to perform all its tasks; considers that the objective should be to work systematically on ways to enable the EU to achieve the objectives of the Lisbon Treaty. Therefore takes the view that the growing sense of risk and threat in Europe requires the urgent establishment of a European Defence Union. This is particularly necessary because of the progressive weakening of security at the EU's borders, particularly in the EU's eastern and southern neighbourhood. The EP is of the opinion that the European Defence Union should be based on a periodic joint assessment of security threats developed by Member States, but must also be flexible enough to meet the security challenges and needs of individual Member States. considers that the EU should devote its own resources to promoting closer and more systematic European cooperation on defence between Member States, including permanent structured cooperation (PESCO). It is convinced that the use of EU funds would be a clear sign of cohesion and solidarity and that this would allow all Member States to increase their military capabilities. The EP takes the view that strengthening European cooperation in the field of defence would contribute to increased efficiency, unity and effectiveness, as well as to an increase in EU assets and capabilities, and would have a potential positive impact on defence research and industrial issues. It underlines that it is only through ever closer cooperation, which should gradually become a genuine European Defence Union, that the EU and its Member States will be able to acquire the technological and industrial capacities needed to enable them to act more quickly, independently and effectively in order to respond to today's threats in a responsible and effective manner. It encourages all Member States to make more binding commitments among themselves by establishing permanent structured cooperation within the Union. It advocates the establishment of a multinational force within PESCO and making this force available for peacekeeping, conflict prevention and the strengthening of international security. It proposes that both political decision-making processes at EU level and national procedures should be shaped in such a way as to enable a rapid crisis response. It encourages the establishment of EU Operational Headquarters as a prerequisite for effective planning, command and control of 
joint operations (Rezolucja..., 2016c). Furthermore, the EP notes that the effects of the economic and financial crisis of 2008 led to restrictions on national defence budgets and that these restrictions were introduced without any coordination between Member States, jeopardising the strategic independence of the Union and the ability of Member States to meet the capability needs of their armed forces, and adversely affected the Union's responsibilities and capabilities as a global guarantor of security. In this context, it stresses the importance of introducing early planning among Member States for strategic investments in the purchase and repair of equipment, and calls on the Union to encourage Member States to meet NATO's capability targets of at least 2\% of GDP in defence spending and $20 \%$ of defence budgets for arms purchases and research and development (Rezolucja..., 2015).

The changes to the CSDP proposed by the EP are accompanied by a desire to give this policy strong democratic legitimacy. In the numerous positions adopted, the EP underlines that it is the only supranational institution that has the right to democratic scrutiny of the CSDP, especially after the entry into force of the Treaty of Lisbon. It also advocates cooperation with national parliaments in the field of CSDP and the adaptation of its own structures in order to ensure optimal supervision of this policy (Rezolucja..., 2010). It should be noted that the EP's demand for democratic control of the CSDP remains, however, in the postulate sphere due to the eminently intergovernmental nature of this policy. Giving democratic legitimacy to the CSDP on a pan-European level would only be possible as a result of fundamental political changes in the EU consisting in the incorporation of supranational mechanisms into the CSDP area, which, due to opposition from Member States, seems unlikely in the foreseeable future.

\section{SUMMARY}

There is no doubt that the effectiveness of the EU's functioning on the international stage requires close cooperation between Member States in the field of security and defence. The instrument of this cooperation is the CSDP, which covers programming objectives, institutions, civilian and military assets and capabilities. The development of the CSDP enables the EU to carry out Petersberg operations (humanitarian and rescue operations, peacekeeping operations 
and crisis management missions) that take place outside the EU. Contrary to its name, the CSDP does not include commitments for the common defence of the Member States and therefore cannot be analysed in terms of military security. This policy combines primarily preventive and military crisis response measures with civilian ones, giving the EU the opportunity to become a comprehensive actor in international relations (Zajączkowski, 2009, p. 50-51). The importance of this policy for confirming the EU's identity in the international arena makes the CSDP a matter of particular interest for the EP. When assessing the EP's position on key CSDP issues, it should be noted that, from a formal and treaty point of view, this body is not a fully-fledged co-decision maker of this policy. This is due to the fact that the EP, as a supranational institution, does not have decision-making powers with regard to the CSDP, which is dominated by intergovernmental cooperation mechanisms and forms an integral part of the CFSP. This means that with regard to CSDP issues, the role of the EP boils down to being primarily an advisory and consultative institution. Non-legislative resolutions adopted by the EP in the field of CSDP are the main instrument for expressing EP opinions in the field of CSDP. However, although they are not legally binding, they are of major political importance. They contain the views of the EP, which, because it is the only democratically legitimate EU institution that by definition represents the peoples of Europe, must be more or less taken into account by the other EU bodies and the Member States. In expressing its position on the most important CSDP issues, the EP can invoke the will of European public opinion, while at the same time shaping it through resolutions. This allows it to play the role of a political influence institution, whose importance goes far beyond its competences under the Treaty, toward the Council of the EU, which is the most important decision-making body of the CSDP. However, the objective of transforming the CSDP into a policy that is also based on transnational cooperation mechanisms and subject to parliamentary scrutiny, as outlined in a number of resolutions by the EP, has not yet been achieved. Despite the changes made to the Lisbon Treaty, the role of the EP in the creation of the CSDP has not increased in line with its expectations. The unification of the EU's external relations by removing the pillars of the EU has not led to the abolition of the specific intergovernmental character of the CSDP. As a result of such Treaty arrangements, the EP is unable to play a role in the area of CSDP that corresponds to the importance of this body in the EU's institutional system. 
Therefore, resolutions remain the main instrument for the implementation of the EP policy in the area of CSDP. In these documents, the EP advocates the development of a strong, unified CSDP based on defined European security interests. The development of a pan-European approach to CSDP issues should be accompanied by the development of military and civilian capabilities of the EU capable of guaranteeing security and responding to crisis situations, especially in the immediate neighbourhood. However, and this is worth emphasising, despite the fact that the EP is in favour of an increase in the EU's strategic importance in the modern world, it does not believe that the EU should play a role similar to that of the USA in international security architecture. This is due to the EP's conviction that security should be achieved first and foremost by civilian means and not by military means, which should be used as a last resort and to take the view that NATO should remain the foundation of collective defence in Europe. The role of the CSDP should be to provide the EU with an autonomous military and civilian capability to meet security challenges in cooperation with other international organisations. At the current level of development of the CSDP, the implementation of the EP opinion in this area depends on decisions taken by intergovernmental bodies of the EU, i.e. the European Council and the Council of the EU. In order for the EP to become a fully-fledged CSDP shaper in relation to these bodies, the concept of establishing a supranational political union within which it would be possible to conduct foreign policy outside the institutions of the national state would have to be materialised.

\section{BIBLIOGRAPHY:}

Bickerton, Ch. J., Irondelle, B., Menon, A. (2011). Security Co - operation beyond the Nation - State: The EU's Common Security and Defence Policy. Journal of Common Market Studies, 49 (1), pp. 1-21.

Chodubski A. (2012). Teorie i metody badań europeistycznych. In: J. Ruszkowski, L. Wojnicz (eds.). Teorie w studiach europejskich. W kierunku nowej agendy badawczej, Szczecin - Warszawa: Instytut Politologii i Europeistyki US, Instytut Europeistyki UW.

Globalna strategia UE na rzecz polityki zagranicznej i bezpieczeństwa. (2016). Downloaded from: https://europa.eu/globalstrategy/sites/globalstrategy/files/ eugs_pl_version.pdf. 
Hürsoy, S. (2002). The New Security Concept and German - French Approaches to the European Pillar of Defence 1990 - 2000. Marburg: Tectum Verlag.

Koziej, S. (2011). Potrzeba nowelizacji strategii bezpieczeństwa Unii Europejskiej. Bezpieczeństwo Narodowe, 20, pp. 19-40.

Rezolucja Parlamentu Europejskiego z dnia 11 maja 2011 r. w sprawie rozwoju wspólnej polityki bezpieczeństwa i obrony po wejściu w życie Traktatu z Lizbony. (2011). Downloaded from: www.europarl.europa.eu/sides/getDoc. do?type $=$ TA\&reference $=$ P7-TA-2011-0228\&language $=$ PL .

Rezolucja Parlamentu Europejskiego z dnia 22 listopada 2012 r. w sprawie wdrażania wspólnej polityki bezpieczeństwa i obrony (na podstawie sprawozdania rocznego Rady dla Parlamentu Europejskiego na temat wspólnej polityki zagranicznej i bezpieczeństwa). (2012). Downloaded from: www.europarl.europa.eu/ sides/getDoc.do?pubRef=-//EP//TEXT+TA+P7-TA-2012-

$-0455+0+\mathrm{DOC}+\mathrm{XML}+\mathrm{V} 0 / / \mathrm{PL} .=\mathrm{TA} \&$ reference $=\mathrm{P} 7-\mathrm{TA}-2011-0228 \&$ language $=\mathrm{PL}$.

Rezolucja Parlamentu Europejskiego z dnia 21 listopada 2013 r. w sprawie wdrażania wspólnej polityki bezpieczeństwa i obrony (na podstawie sprawozdania rocznego Rady dla Parlamentu Europejskiego na temat wspólnej polityki zagranicznej i bezpieczeństwa). (2013). Downloaded from: www.europarl.europa.eu/sides/getDoc.do?pubRef=-//EP//TEXT+TA+P7-TA-20130513+0+DOC+XML+V0//PL.

Rezolucja Parlamentu Europejskiego z dnia 10 marca 2010 r. w sprawie wdrażania europejskiej strategii bezpieczeństwa oraz wspólnej polityki bezpieczeństwa i obrony. (2010). Downloaded from: www.europarl.europa.eu/sides/getDoc. do ?type $=$ TA\&reference $=$ P7-TA-2010 -0061 \&language $=$ PL.

Rezolucja Parlamentu Europejskiego z dnia 21 maja 2015 r. w sprawie wdrażania wspólnej polityki bezpieczeństwa i obrony (na podstawie sprawozdania rocznego Rady dla Parlamentu Europejskiego na temat wspólnej polityki zagranicznej i bezpieczeństwa). (2015). Downloaded from: www.europarl.europa.eu/sides/getDoc.do?pubRef=-//EP//TEXT+TA+P8-TA-2015$0213+0+\mathrm{DOC}+\mathrm{XML}+\mathrm{V} 0 / / \mathrm{PL}$.

Rezolucja Parlamentu Europejskiego z dnia 13 kwietnia 2016 r. w sprawie UE w zmieniającym się globalnym otoczeniu - świat bardziej połączony, skonfliktowany i złożony. (2016a). Downloaded from: www.europarl.europa.eu/sides/ getDoc.do?pubRef=-//EP//TEXT+TA+P8-TA-2016-0120+0+DOC+XML+V0// PL.

Rezolucja Parlamentu Europejskiego z dnia 23 listopada 2016 r. w sprawie wdrażania wspólnej polityki bezpieczeństwa i obrony (na podstawie sprawozdania rocznego Rady dla Parlamentu Europejskiego na temat wspólnej polityki zagranicznej i bezpieczeństwa). (2016b). Downloaded from: www. 
europarl.europa.eu/sides/getDoc.do?pubRef=-//EP//TEXT+TA+P8-TA-20160440+0+DOC+XML+V0//PL.

Rezolucja Parlamentu Europejskiego z dnia 22 listopada 2016 r. w sprawie Europejskiej Unii Obrony. (2016c). Downloaded from: www.europarl.europa.eu/sides/ getDoc.do?pubRef=-//EP//TEXT+TA+P8-TA-2016-

$-0435+0+\mathrm{DOC}+\mathrm{XML}+\mathrm{V} 0 / / \mathrm{PL}$.

Rezolucja Parlamentu Europejskiego z dnia 13 grudnia 2017 r. w sprawie sprawozdania rocznego w sprawie realizacji wspólnej polityki bezpieczeństwa i obrony. (2017). Downloaded from: www.europarl.europa.eu/sides/getDoc. do?pubRef=-//EP//TEXT+TA+P8-TA-2017-0492+0+DOC+XML+V0//PL.

Traktat o Unii Europejskiej (wersja skonsolidowana). Dz. U. UE. 2016, nr C 202, poz. 13.

Zajączkowski, K. (2009). Unia Europejska jako aktor globalny - aspekty polityczno - obronne. Studia Europejskie, 1, pp. 37-58.

Zięba, R. (2005a). Europejska Polityka Bezpieczeństwa i Obrony. Warszawa: Wydawnictwo Sejmowe.

Zięba, R. (2005b). Wspólna Polityka Zagraniczna i Bezpieczeństwa Unii Europejskiej. Warszawa: Wydawnictwo Sejmowe. 